\title{
Dispersion of the bank vole in fine- and coarse-grained mosaics of deciduous and mixed coniferous forests
}

\author{
Włodzimierz CHĘTNICKI and Maria MAZURKIEWICZ
}

\begin{abstract}
Chętnicki W. and Mazurkiewicz M. 1994. Dispersion of the bank vole in fine- and coarse-grained mosaics of deciduous and mixed coniferous forests. Acta theriol. 39: 127-142.

Density and distribution of the bank vole Clethrionomys glareolus (Schreber, 1780) was studied in 1986-1989 on two forest plots (one of 5.4 and one of 5.8 ha) that differed with respect to their mosaic character. On both plots densities of bank voles were similar in different habitats. The same trap sites were used by voles in a similar way in successive study years. Spatial variations in habitat use were primarily related to the density of plant cover and its spatial distribution providing shelter from predators. Frequency and intensity of use of trap sites by voles was positively correlated with the percent cover of shrubs and tall herbaceous plants. It was negatively correlated with the percent area without herb cover and with the percent cover of photophilous herbs. Using the correlation method, it was possible to estimate the effect of a given environmental factor on the distribution of bank voles only when the range of spatial variation of this factor was large.

Institute of Biology, Warsaw University Białystok Branch, Świerkowa 20B, 15-950 Białystok, Poland (WC); Department of Vertebrate Ecology, Institute of Ecology, Polish Academy of Sciences, Dziekanów Leśny, 05-092 Łomianki, Poland (MM)

Key words: Clethrionomys glareolus, density, space use, habitat structure
\end{abstract}

\section{Introduction}

Torest habitats offer differential living conditions to populations of small mammas. Different habitat types, according to Morris's (1987) definition can be distinguiched on the basis of their physical properties such as soil types. Habitat patches canbe more or less suitable for rodents, depending on the species composition and richess of the vegetation. On the other hand, it is argued that the distribution of nany animal species is more dependent on differences in the spatial distribution of tie vegetation than on its species composition (e.g. Rosenzweig and Winakur 1961).

The bank vole Clethrionomys glareolus (Schreber, 1780), a common species in all ypes of forest habitats (Hansson 1978, Pucek 1983), can reach different denities in patches of the same habitat, and similar densities in various habitat type (Mazurkiewicz and Rajska-Jurgiel 1978, Jensen 1982, Mazurkiewicz 1984). Scace investigations of the distribution of this species over large forest area did 
not show a direct effect of the habitat type on population density. It has been found, however, that the dispersion of bank voles in a mosaic of forest habitats is not uniform, and their densities in a particular habitat type depend on the size of the patch in which it occurs and on the surrounding habitats (Kovalevsky et al. 1971, Kovalevsky and Korenberg 1976, Gubar 1974). Study of the effects of the habitat structure on the bank vole populations shows that habitat suitability is determined by the abundance and spatial distribution of a factor that can generally be termed shelter (Southern and Lowe 1968, Hansson 1978, Wiger 1982, Mazurkiewicz 1984, Geuse 1985, Mazurkiewicz 1986, 1991, 1994).

The purpose of this study was to find out whether the density of bank voles and their use of space was more dependent on the habitat type (i.e. species composition of the vegetation) and patch size, or more on the distribution of the habitat features providing shelter.

\section{Study area, methods and material}

The study was conducted in two forest complexes of Poland: the Kampinos Forest (plot A) $\left(52^{\circ} 35^{\prime} \mathrm{N}, 20^{\circ} 81^{\prime} \mathrm{E}\right)$ and the Knyszyn Forest (plot B) $\left(53^{\circ} 36^{\prime} \mathrm{N}, 23^{\circ} 24^{\prime} \mathrm{E}\right)$. Both these areas were covered with the same habitat types (deciduous forest, mixed coniferous forest, and a transitional forest between them) at a similar age of the tree stand (0-140 years old in plot A and 0-160 years old in plot B). They differed, however, with respect to their mosaic character. In plot A, different habitats occurred in many patches of different sizes, whereas in plot B the mixed coniferous forest and the deciduous forest occurred in two large patches separated with the intermediate habitat forming an ecotone (Fig. 1). Plot A bordered on an alder swamp from three sides, whereas the habitats surrounding plot B did not differ from those on the plot itself.

Capture-mark-release (CMR) method was used from May 1987 to October 1989 on plot A and from July 1986 to October 1989 on plot B. A $15 \times 15$ m grid of live-traps was set up, with 240 traps on plot A and 256 traps on plot B, which means that these plots covered 5.4 ha and 5.8 ha, respectively. On

PLOT A

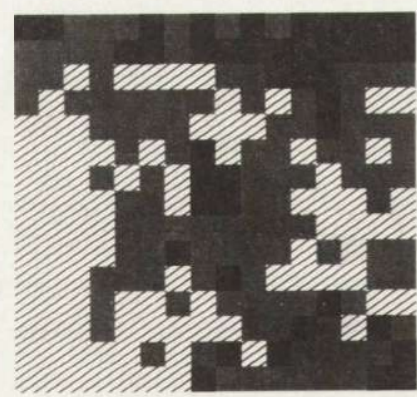

PLOT B

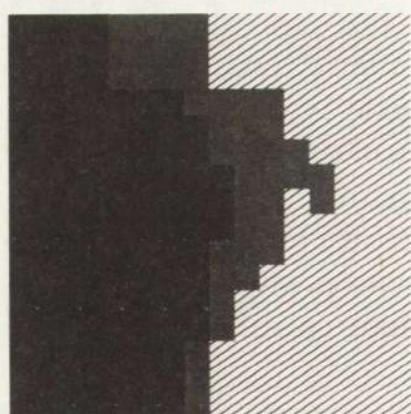

-1
$\geqslant-2$
$y-3$

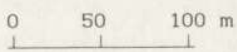

Fig. 1. Distribution of different habitat types on plot A (Kampinos Forest) and B (Knyszyn Forest). 1 - deciduous forest, 2 - mixed coniferous forest, 3 - transitional form between them (ecotone). 
plot A, 0.95 ha was covered by the deciduous forest (DF), 2.07 ha by the mixed coniferous forest (MCF), and 2.38 ha by the intermediate ecotone (ECO). Plot B comprised 2.59 ha of DF, 2.23 ha of $\mathrm{MCF}$, and 0.95 ha of ECO.

In 1986 three trapping series were run on plot B. In 1987 four series were run on both the plots at about 42-day intervals (late May, early July, late August, mid-October). In 1988 and 1989 an additional series was run in June (three weeks after the end of the May series).

Each trapping series lasted for seven days, and traps were checked twice daily. The captured voles were individually marked by toe clipping. The date and the place of capture were noted (other measurements such as body weight, sex, and sexual activity are not analysed in this paper).

The plant cover was measured in August 1989 (plot A) and August 1987 (plot B). The cover of different plant layers and species richness were estimated on areas of $225 \mathrm{~m}^{2}$ centred upon each trap. In the Kampinos Forest (plot A), densities of individual species of tall and short trees and shrubs were estimated as the number of individuals per $225 \mathrm{~m}^{2}$, whereas the cover of the shrub and herb layers was estimated using a 7-degree Braun-Blanqet scale. In the Knyszyn Forest (plot B), the plant cover was estimated by the Braun-Blanqet method and by the 11-point scale of Domin-Krajin (after Barbour et al. 1980, modified).

On plot A, the layer of tall trees (above $20 \mathrm{~m}$ ) was dominated by Quercus robur and Pinus sylvestris, whereas on plot B by P. sylvestris and Picea abies. This last species is an important component of the tree stand in the Knyszyn Forest, the geographic range of which does not reach the Kampinos Forest. On both the plots, the layer of short trees (below $20 \mathrm{~m}$ ) was dominated by Carpinus betulus; the next most numerous species were $Q$. robur on plot A and $P$. abies on plot B. On plot A, the highest density of tall trees occurred in MCF, and on plot B in ECO. The density of short trees was similar in different habitats on plot A. On plot B, it was highest in DF and lowest in MCF (Table 1).

The shrub layer of different habitats on plot A was dominated by Frangula alnus. Also C. betulus and Corylus avellana were abundant. The shrub layer on plot B was dominated by $P$. abies and C. avellana. The highest densities of $P$. abies were observed in MCF, whereas in DF and ECO, $C$. avellana was most abundant. The shrub layer cover on plot B was twice as high as on plot $\mathrm{A}$, and on both the plots it was highest in MCF and lowest in DF. The number of species in the shrub layer was similar on both the plots. The highest species diversity occurred in ECO on plot A and in MCF on plot B (Table 1).

The herb layer of different habitats on plot A was dominated by Pteridium aquilinum, Convallaria maialis and Carex sp. in DF, by P. aquilinum, C. maialis, Vaccinium myrtillus, and Calamagrostis arundinacea in ECO, and by $P$. aquilinum, V. myrtillus, and C. arundinacea in MCF. The dominant species of the herb layer on plot B were Oxalis acetosella, Galeobdolon luteum, and Hepatica nobilis in DF, O. acetosella, G. luteum, and V. myrtillus in ECO, and V. myrtillus, O. acetosella, and Carex sp. in MCF. The herb layer cover on plot A was twice as high in ECO and MCF as in DF, whereas on plot B the opposite was true: the highest herb layer cover occurred in DF and the lowest in MCF. The species richness of the herb layer was similar in different habitats of plot A. On plot B, it was highest in DF and lowest in MCF (Table 1, Appendix).

The analysed material consisted of 3884 captures of 786 bank voles on plot A, and of 4470 captures of 914 bank voles on plot B. Among other rodents captured in the study plots, the yellow-necked field mouse Apodemus flavicollis was most abundant. Occasionally captured were the striped field mouse Apodemus agrarius, field vole Microtus agrestis, wood mouse Apodemus sylvaticus, and on plot B, the common vole Microtus arvalis.

\section{Statistical methods of data processing}

Densities of the bank vole were estimated for successive trapping series in all the study years for the whole plots and for different habitat types separately. Only voles with the centres of their home ranges within a habitat type were included in the density estimate in this habitat (each individual was counted only once). Mean densities of bank voles in successive years were calculated as the mean 
number of individuals per ha per trapping series. The $\chi^{2}$ test was used to compare number of rodents between years, plots and different habitat types.

Space use by bank voles was characterized by two indices: (1) Intensity of use of trap sites (IU), defined as the number of individuals captured at each trap site in successive years and over the study period. This index was highly positively correlated with the number of captures per trap site (for all compirisons of Spearman rank correlation coefficients ranged between 0.89 and $0.98, p<0.001$ ). (2) Freqtency of use of trap sites (FU), defined as the number of trapping series in which a given trap site vas visited. The maximum number of series in which a given site could be occupied was 14 for plot $A$ and 17 for plot $B$.

The effect of various environmental factors on space use by the bank vole was estimated by using Speaman rank correlation between numbers of individuals captured at particular trap sites (IU) in successive study years and a given variable. These variables included plant cover or density and species richness of the vegetation in different layers (tall and short trees, shrubs, herbs), and cover with lifferent species of herbaceous plants.

Tie joint effect of environmental factors determining space use by voles was analysed by using a stepwise variable selection in which dependent variables were represented by the indices defined above (IU and FU). The analysis was made in three steps. At the first step, gross factors were taken into acount such as cover or density and species richness of different vegetation layers. At the second step, the effect of individual plant species from different layers was analysed. Factors discerned in these two steps were used for the final analysis. In this analysis the percentage of the herb cover was replared by the area not covered with the herb layer, because in some cases a positive effect of the total ierb cover as well as that of some species cover was found.

In the stepwise variable selection analysis, the habitat variables expressed as numbers of indiviluals were transformed by using the formula $y^{\prime}=\sqrt{y+0.5}$ and the data expressed as the perceitage cover by using the formula $y^{\prime}=\arcsin \sqrt{y / 100}$ (Zar 1984).

\section{Results}

Nean bank vole densities on plot A were similar in successive years and in different habitat types. They were lower in DF than in MCF and ECO but differences were not significant (Table 2). On plot B, the mean density in 1987 was significantly lower than in the other years and than the mean density on plot $\mathrm{A}$ in the same year $\left(\chi^{2}=12.91, p<0.001\right)$. On plot $\mathrm{B}$, as on plot $\mathrm{A}$, no significant diffeences were found in mean densities between different habitat types in succtssive years (Table 2).

Table 2. Density of bank voles in different years (mean number of individuals captured per trapping series oer ha) in different habitats of both the plots. Values of $\chi^{2}$ and $p$ concern comparisons between years. There were no significant differences between habitats. For abbreviations see Table 1 .

\begin{tabular}{|c|c|c|c|c|c|c|c|c|c|c|c|}
\hline & \multicolumn{5}{|c|}{ Plot A } & \multicolumn{6}{|c|}{ Plot B } \\
\hline & 1987 & 1988 & 1989 & $\chi^{2}$ & $p$ & 1986 & 1987 & 1988 & 1989 & $\chi^{2}$ & $p$ \\
\hline DF & 12.6 & 10.5 & 12.6 & 0.22 & 0.89 & 16.2 & 11.2 & 19.3 & 22.8 & 10.80 & 0.01 \\
\hline MCF & 18.8 & 21.7 & 24.1 & 1.33 & 0.51 & 23.8 & 9.4 & 13.0 & 19.3 & 16.74 & 0.00 \\
\hline ECO & 19.3 & 17.6 & 21.4 & 0.86 & 0.65 & 16.8 & 6.3 & 10.5 & 13.7 & 4.75 & 0.19 \\
\hline $\mathrm{T}$ & 18.0 & 18.0 & 20.9 & 1.65 & 0.44 & 19.3 & 9.7 & 15.4 & 20.0 & 23.56 & 0.00 \\
\hline
\end{tabular}


Table 3. Spearman rank correlation coefficients between numbers of bank voles captured at the same trap sites in following years on plots A and B $(p<0.05$, * indicates $p<0.01$, ns - not significant). For abbreviations see Table 1 .

\begin{tabular}{|c|c|c|c|c|c|}
\hline & \multirow{2}{*}{ Year } & \multirow{2}{*}{ Habitat } & \multicolumn{3}{|c|}{ Plot B } \\
\hline & & & 1987 & 1988 & 1989 \\
\hline \multirow{4}{*}{\multicolumn{2}{|c|}{1986}} & DF & $0.54^{*}$ & $0.64^{*}$ & $0.62 *$ \\
\hline & & MCF & $0.36^{*}$ & $0.33^{*}$ & 0.22 \\
\hline & & ECO & 0.39 & ns & $0.58 *$ \\
\hline & & $\mathrm{T}$ & $0.46^{*}$ & $0.47^{*}$ & $0.47^{*}$ \\
\hline \multirow{4}{*}{\multicolumn{2}{|c|}{1987}} & DF & & $0.65^{*}$ & $0.57^{*}$ \\
\hline & & MCF & & $0.27^{*}$ & $0.30^{*}$ \\
\hline & & ECO & & 0.33 & 0.37 \\
\hline & & $\mathrm{T}$ & & $0.51^{*}$ & $0.46^{*}$ \\
\hline \multirow{4}{*}{\multicolumn{2}{|c|}{1988}} & DF & 0.40 & & $0.69^{*}$ \\
\hline & & MCF & $0.46^{*}$ & & $0.37^{*}$ \\
\hline & & ECO & $0.48^{*}$ & & $0.41^{*}$ \\
\hline & & $\mathrm{T}$ & $0.48^{*}$ & & $0.57^{*}$ \\
\hline \multirow{4}{*}{\multicolumn{2}{|c|}{1989}} & DF & $\mathrm{ns}$ & $0.63^{*}$ & \\
\hline & & MCF & $0.39^{*}$ & $0.66^{*}$ & \\
\hline & & ECO & $0.39^{*}$ & $0.39^{*}$ & \\
\hline & & $\mathrm{T}$ & $0.40^{*}$ & $0.55^{*}$ & \\
\hline
\end{tabular}

Use of space

Similarity in the intensity of using different trap sites between years was analysed by correlation between numbers of individuals captured at the same trap sites in successive years. A similarity was found in the intensity of using the same sites in successive years on both the plots. The highest correlation coefficients were obtained for $\mathrm{ECO}$ and $\mathrm{MCF}$ on plot $\mathrm{A}$, and for DF on plot B (Table 3).

Spatial clumping of bank voles was analysed by examining the distributions of trap sites with a defined number of captured individuals (mean for all the study years). The distributions were compared with the Poisson distribution by using the $\chi^{2}$ test. It was found that the distribution of voles in different habitat types on plot A was clumped (Fig. 2). On plot B, the largest differences in space use were observed in DF (clumped distribution). MCF was used uniformly, and ECO at random (Fig. 2). On each of the plots analysed as a whole, the distribution of voles was clumped (Fig. 2).

Similar use of the same places in successive years and also differences in the spatial clumping of voles can be related to the distribution and species composition of the vegetation. Further analysis concerned the effect of these habitat variables on space use in bank voles.

\section{Univariate correlations}

A habitat variable was considered to have a significant effect on the intensity of the use of trap sites (IU) if it was significantly correlated with IU in all the study years.

In DF on both the plots, IU was positively correlated with shrub cover and also with species richness of shrubs on plot B. It was negatively correlated with species richness of tall trees. Among the herb layer species in DF on plot A, IU declined with increasing cover of $C$. maialis. In DF on plot B, IU increased with increasing cover of Urtica dioica, Asperula odorata, and Fragaria vesca, whereas it decreased with increasing cover of Daphne mezereum, Lathyrus vernus, and Carex sp. (Table 4). 


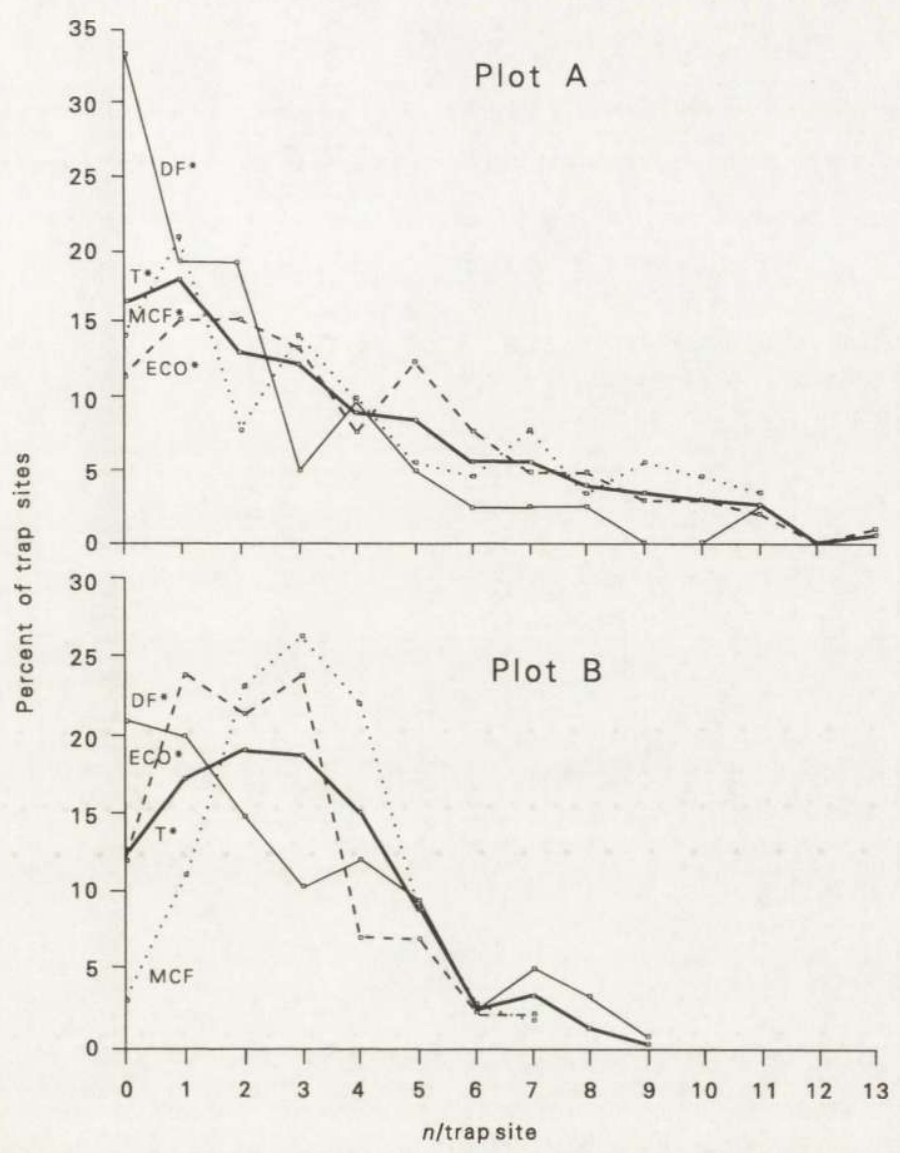

Fig. 2. Percentage distribution of trap sites according to the number of voles captured on plots A and B. Empirical distributions were compared with the Poisson distribution by using $\chi^{2}$ test. * - concordances statistically significant at $p<0.001$. For abbreviations see Table 1 .

In MCF on plot A, IU was positively correlated with shrub and herb cover. When the cover of $P$. aquilinum was excluded from herb cover, the correlation between IU and the remaining part of the herb layer became insignificant. Among the herb layer species, IU was positively correlated with the cover of $P$. aquilinum, Trientalis europaea and with $V$. myrtillus. It was negatively correlated with short tree cover. In MCF on plot B, no significant correlations, recurring year after year, were found between IU and the analysed habitat variables.

In ECO on plot A, IU was positively correlated with shrub cover and species richness of shrubs. Like in MCF, when the cover of $P$. aquilinum was excluded from the herb layer, the correlation of IU with this layer became insignificant. Among the herb layer species, IU was positively correlated with the cover of $P$. aquilinum. In ECO on plot B, no significant correlation, recurring in all the study years, was found between IU and the analysed habitat variables (Table 4). 


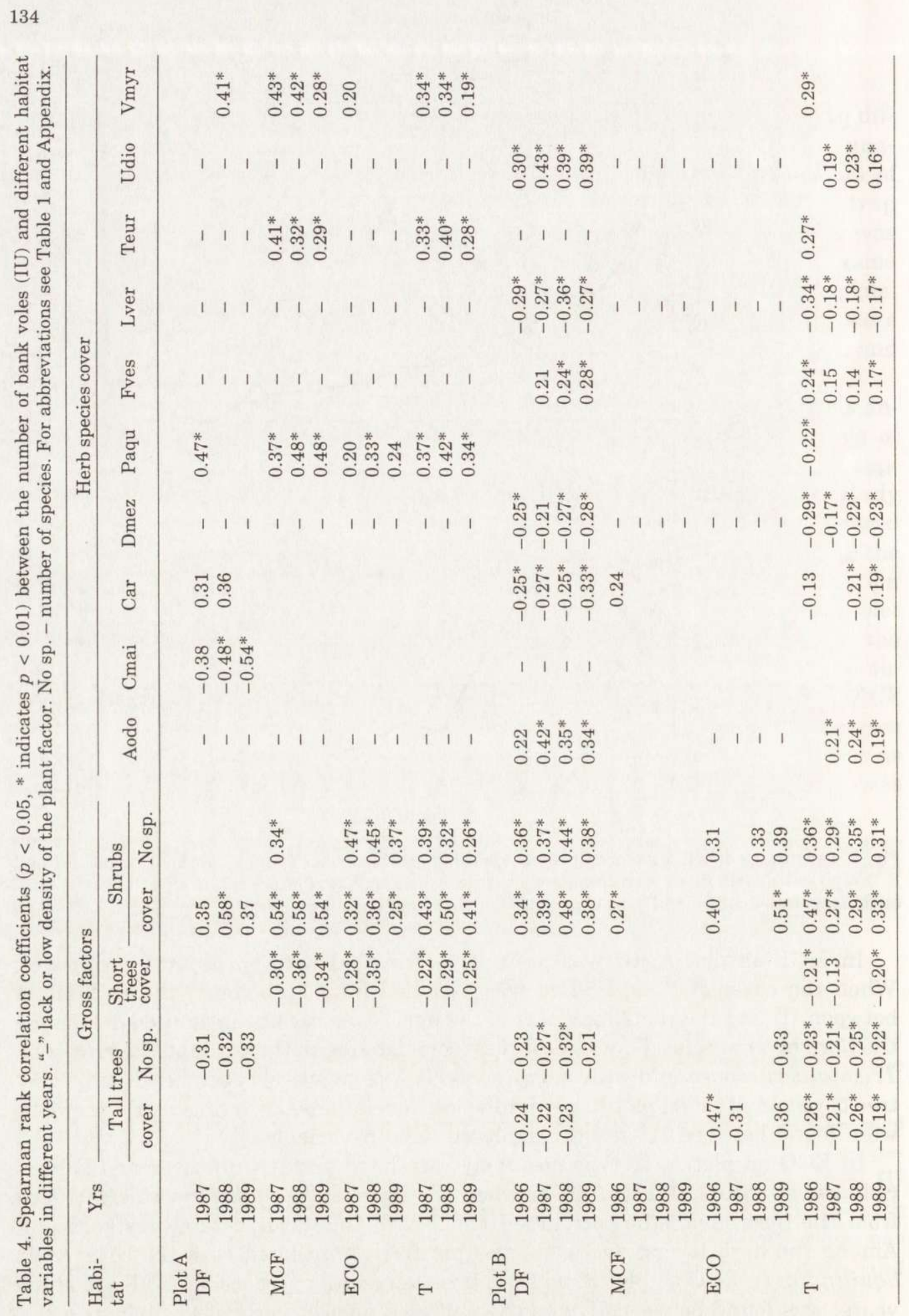


On both the plots taken as a whole, IU was positively correlated with shrub cover and species richness, and negatively correlated with short tree cover (plot A) and cover and species richness of tall trees (plot B). The correlation with the herb layer cover became insignificant when the cover of $P$. aquilinum was excluded. Among herb layer species, IU was positively correlated with the cover of $P$. aquilinum, T. europaea, and V. myrtillus (plot A), and Fragaria vesca (plot B). On plot $\mathrm{B}$, IU was negatively correlated with the cover of $D$. mezereum and $L$. vernus (Table 4).

\section{Multivariate correlations}

The set of habitat variables significantly affecting use of space by voles, as indicated by the model of multivariate correlation, essentially comprises the variables for which significant Spearman rank correlations with IU were found, occurring in each study year (Tables 4 and 5 ).

In $\mathrm{DF}$ on plot $\mathrm{A}$, intensity (IU) and frequency (FU) of use of trap sites were positively correlated with shrub cover and the cover of Carex sp. They were negatively correlated with the cover of $C$. maialis. FU was negatively correlated with densities of $C$. betulus and Pinus sylvestris in the layer of tall trees. These factors explained $61 \%$ of the variation in IU and $62 \%$ of the variation in FU. In DF on plot B, IU and FU were positively correlated with shrub cover and species richness of shrub, cover of $P$. aquilinum and $U$. dioica, and also with Mercurialis perennis. They were negatively correlated with the percentage of area not covered with the herb layer, and with the cover of $L$. vernus. IU was positively correlated with the cover of Betula verrucosa in the layer of tall trees, whereas FU was negatively correlated with this factor. The variables that entered the model explained $65 \%$ of the variation in IU and $59 \%$ of the variation in FU (Table 5).

In $\mathrm{MCF}$ on plot $\mathrm{A}, \mathrm{IU}$ and FU were positively correlated with shrub cover and negatively with area not covered with the herbs and cover of $M$. pratense. These factors accounted for $61 \%$ of the variation in IU and FU. In MCF on plot B, IU and FU were positively correlated with species richness of shrubs and with the cover of $U$. dioica. Moreover, FU was negatively correlated with species richness of short trees. These variables explained only $10 \%$ of the variation in IU and $13 \%$ in FU (Table 5).

In $\mathrm{ECO}$ on plot $\mathrm{A}, \mathrm{IU}$ and $\mathrm{FU}$ were positively correlated with species richness of shrubs, whereas negatively with area not covered with the herbs. The cover of Carex sp. and $P$. aquilinum had a positive effect only on IU. The proportion of explained variation was $59 \%$ for IU and $46 \%$ for FU. In ECO on plot B, IU was positively correlated with the cover of $C$. avellana, and negatively correlated with the cover of $Q$. robur in the shrub layer. In addition, FU was negatively correlated with the cover of Galeopsis speciosa and Paris quadrifolia. These variables explained $41 \%$ of the variation in IU and $50 \%$ of the variation in FU (Table 5).

In both types of mosaics (each plot taken as a whole), the environmental factors with positive effects on IU and FU were shrub cover and species richness of shrubs 
Table 5. Habitat variables entered to the stepwise variable selection model which had significant effect on the intensity (IU) and frequency (FU) of use of trap sites by bank voles in different habitats and on the whole plots. "Empty" area - percentage of area not covered with the herb layer, No sp. number of species, "+" - denotes positive effect, "-" - negative effect $(p<0.01$, * indicates $p<0.001)$. $R^{2}$ - percent of variation explained by a set of factors. For abbreviations see Table 1 and Appendix.

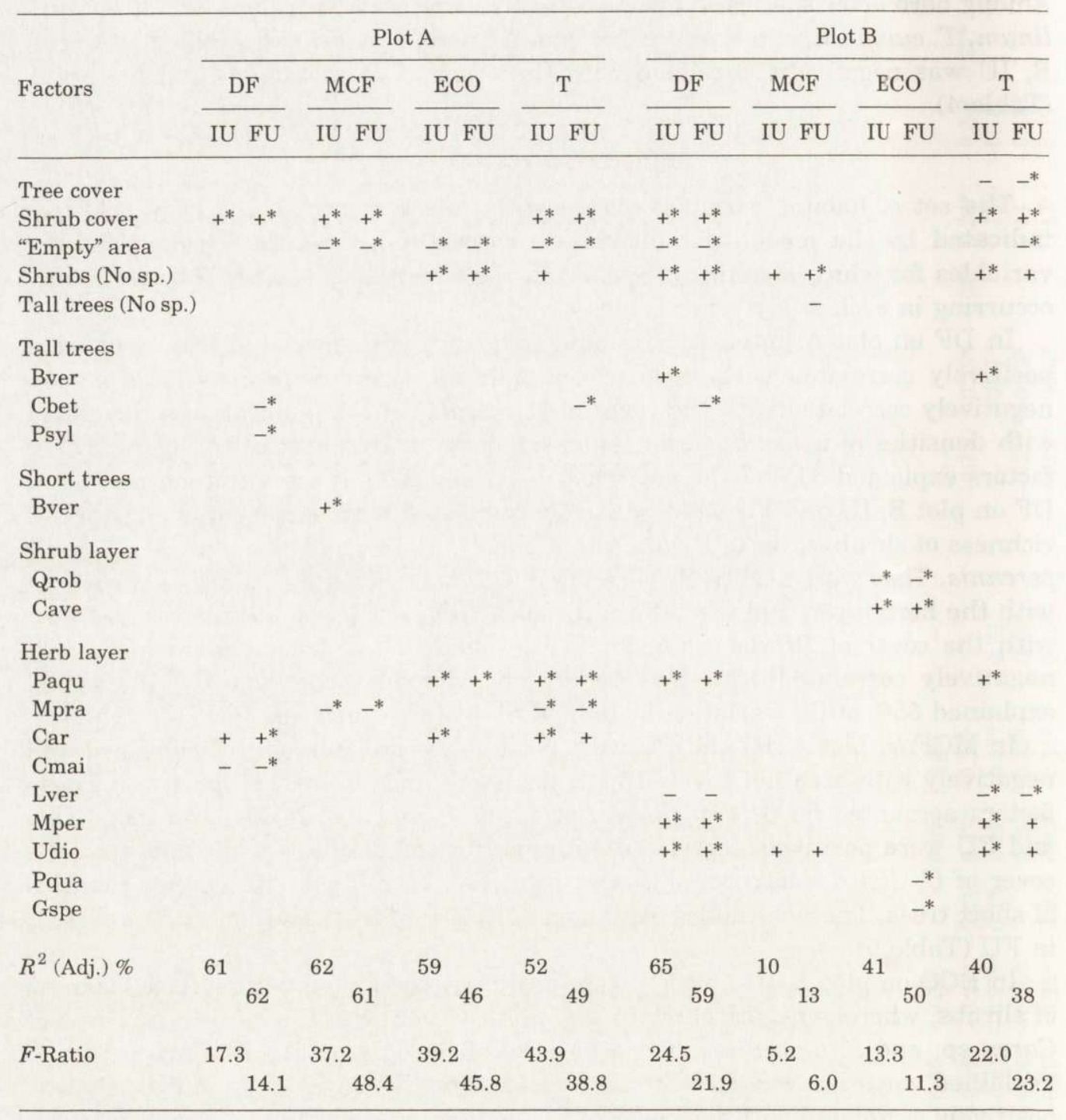

(only on plot B), whereas those with negative effects were area not covered with the herbs (plot A) and tall tree cover (plot B). Among the herb layer species, the cover of $P$. aquilinum and Carex sp. (on plot A), and $U$. dioica and $M$. perennis (plot B) entered the model as they were positively correlated with IU and FU. Also the cover of $M$. pratense (plot A) and L. vernus (plot B) were included as they 
had negative effect. Additional factors that entered the model with IU on plot B were the cover of $B$. verrucosa among tall trees and $P$. aquilinum in the herb layer which had a positive effect. Percentage area not covered with the herbs had a negative effect on FU. All these factors explained $52 \%$ of the variation in IU and $49 \%$ of the variation in $\mathrm{FU}$ on plot $\mathrm{A}$, and $40 \%$ of the variation in IU and $38 \%$ of the variation in $\mathrm{FU}$ on plot $\mathrm{B}$.

\section{Discussion}

This study did not show a direct effect of habitat type on the density of the bank vole. Differences in vole densities observed in various forest types are usually considered as being related to the available food supply (Kalela 1962, Aulak 1970, Hansson 1979, Bashenina 1981). On the other hand, it is known that bank voles are characterized by a high plasticity with respect to their diet, depending on what is available in different forests (Holišova 1971, Gębczyńska 1983). Presumably, differences in the available food supply were too small in the study habitats to have an effect on population density. Similarly, the character of the mosaic in the two forest types (size of habitat patches and their configuration) did not influence the density of voles. The present results suggest that the distribution of the bank vole population in the two mosaics of forest habitats was determined by the supply and distribution of specific microhabitat variables to a higher degree than by the habitat type and patch size (macrohabitat variables).

Based on the results of the multivariate correlations, it may cautiously be stated that the environmental factors with most positive effect on the frequency and intensity of space use by bank voles were related to cover, which served as a protection from predators. These factors comprised the cover of shrubs and tall herb layer such as Pteridium aquilinum, Urtica dioica, Carex sp., and Mercurialis perennis. Tall herb layer can perform a double function of shelter and food (Kikkawa 1964, Gębczyńska 1983, Gurnell 1985, Pelikán 1986). It seems, however, that the protective role is of primary importance, as most of the herb layer species occurring in the study plot and not included to the model is consumed by the voles (Watts 1968, Gębczyńska 1983). This conclusion is further supported by the fact that the effect of this layer on the space use by voles lost its significance when the cover of $P$. aquilinum was excluded.

On the two plots, both the percentage cover of the shrub layer and the species richness of the shrub layer had a positive effect on space use by the bank vole. This suggests that, like the tall herb layer, the shrub layer also performs a double function of food and shelter. It seems however, that the most important function of the shrub layer is protection from predators. The study of the macrostructure of a forest, in which habitat structure was characterized by mean values of habitat variables for a given patch, showed that density of bank voles and the use of habitats depended on the density and distribution of the understorey (Mazurkie- 
wicz 1984, 1986). The effect of the habitat structure on differences of the dispersion of bank voles was also analysed by Geuse (1985). He found that the density of bank voles per trap site depended on the abundance of small dry debris, cover of $P$. aquilinum and deciduous undergrowth, also on density of Prunus sp. and Rhododendron praecocs in the shrub layer. Also landscape studies revealed that the occurrence of the bank voles in forest patches surrounded by unsuitable habitat (matrix) was significantly positively related to the abundance of tall herbaceous plants such as $U$. dioica, $R$. fructicosus, and R. idaeus (Apeldoorn et al. 1992).

The model also includes habitat variables that negatively influence space use by the bank vole. Presumably, some of them have indirect effects that can be seen when other cover factors important to voles are absent. They include the cover of tall trees (plot B), and also photophilous plants of the herb layer, such as Melampyrum pratense and Convallaria maialis (plot A), and Galeopsis speciosa (plot B), or plants occurring under the canopy of tall trees, such as Paris quadrifolia or Lathyrus vernus (plot B). It is worth noting that most of these herbs are preferred food of the bank voles (Bashenina 1981). Also the proportion of area not covered with the herb layer had a negative effect on the distribution of the bank vole. A negative effect of the "empty" space was also noted by other authors (Gurnell 1985, Dicman and Doncaster 1987, Apeldoorn et al. 1992). It is understandable that such space (no shelters, no food) is useless to the bank vole.

The present results revealed a methodological problem concerning the possibility of getting a univocal answer whether or not the effect of a given factor on bank vole distribution is significant when using a correlation method. An example will illustrate this problem. In this study, the percentage cover of the shrub layer, besides other factors, had a significant effect on the distribution of bank voles (Table 4). In all the habitats of plot A, the cover of the shrub layer showed large differences as estimated by the coefficient of variation $(\mathrm{V}=131 \%$ in $\mathrm{DF}, \mathrm{V}=93 \%$ in $\mathrm{MCF}$, and $\mathrm{V}=103 \%$ in ECO). This variation could account for the clumped distribution of the bank vole. On plot $\mathrm{B}$, the mean cover of the shrub layer in different habitats was higher than on plot A (Table 1), and large difference were observed in the cover of shrubs among habitats. Hence, in DF, where the shrub cover was smallest and most variable $(\mathrm{V}=71 \%)$, it could determine the clumped distribution of individuals. However, in MCF, where the shrub cover was high and little variable $(\mathrm{V}=37 \%)$, no significant effect of this factor was found, and bank voles uniformly used this habitat. But when the plot was analysed as a whole, that is, when the range of spatial variation in shrub cover was larger $(\mathrm{V}=61 \%)$, this factor had a positive effect. Lack of correlation with a specified environmental factor does not have to indicate that this factor is not important to the species.

To sum up, the present results and the results of other authors show that the distribution of the bank vole in a mosaic of forest habitats primarily depends on the density of plant cover and on the spatial distribution of the vegetation providing shelter from predators. Bank voles show preference for habitat patches with dense plant cover of different types, depending on the habitat type. This 
preference seems to persist throughout the season but this subject needs a more detailed analysis and will be presented in a separate paper.

Acknowledgements: Many thanks are due to Drs E. Brzosko and E. Pirożnikow for the description of the plants on the study areas. We are grateful to A. Bartha, J. Kupryjanowicz and J. Łobodzińska for their help in field work, and two anonymous reviewers for their comments on the earlier version of the manuscript.

\section{References}

Apeldoorn R. C. van., Oostenbrink W. T., van Winden A., and van der Zee S. 1992. Effects of habitat fragmentation on the bank vole, Clethrionomys glareolus in an agricultural landscape. Oikos 65 : 265-274.

Aulak W. 1970. Small mammal communities of the Białowieża National Park. Acta theriol. 15: 465-515.

Barbour M. G., Burk J. H. and Pitts W. D. 1980. Terrestrial plant ecology. The Benjamin Cummings Publishing Company, Inc. Menlo Park, California; Reading, Massachusetts; London; Amsterdam; Don Mills, Ontario; Sydney: 1-604.

Bashenina N. V. (ed) 1981. Evropejskaja ryżaja polevka. Izd. Nauka, Moskva: 1-351.

Dickman C. R. and Doncaster C. P. 1987. The ecology of small mammals in urban habitats. I. Populations in a patchy environment. J. Anim. Ecol. 56: 629-640.

Gębczyńska Z. 1983. Feeding habits. [In: Ecology of the bank vole. K. Petrusewicz, ed]. Acta theriol. 28, Suppl. 1: 40-49.

Geuse P. 1985. Spatial microhabitat of bank voles and wood mice in a forest in central Belgium. Acta zool. Fenn. 173: 61-64.

Gubar J. P. 1974. Stacji krasnoj polevki (Clethrionomys rutilus Pall.) Onežskogo pouostrova. Fauna i Ecol. Živ., Nauka, Moskva: 174-188.

Gurnell J. 1985. Woodland rodent communities. [In: The ecology of woodland rodents: bank voles and wood mice. J. R. Flowerdew, J. Gurnell and J. H. W. Gipps, eds]. Symp. zool. Soc. Lond. 55: 377-411.

Hansson L. 1978. Small mammal abundance in relation to environmental variables in three Swedish forest phases. Stud. Forest. Snee. 147: 5-39.

Hansson L. 1979. Condition and diet in relation to habitat in bank voles, Clethrionomys glareolus: population or community approach? Oikos 33: 55-63.

Holišova V. 1971. The food of Clethrionomys glareolus at different population dynamics. Acta Sci. nat. Brno 5: 1-43.

Jensen T. S. 1982. Habitat distribution, home range and movements of rodents in mature forest and reforestation. Acta zool. Fenn. 171: 305-307.

Kalela O. 1962. On the fluctuations in the numbers of arctic and boreal small rodents as a problem of production biology. Ann. Acad. Sci. Fenn., Ser. A IV 66: 1-38.

Kikkawa J. 1964. Movement, activity and distribution of the small rodents Clethrionomys glareolus and Apodemus sylvaticus in woodland. J. Anim. Ecol, 33: 259-296.

Kovalevsky J. V., Karpenko E. I. and Katenina N. D. 1971. Methods for large-scale mapping of the distribution and abundance of small forest rodents. Fauna i Ekologija Gryzunov 10: 172-186. [In Russian with English summary]

Kovalevsky J. V. and Korenberg E. I. 1976. The determination of the norm of quantitative accounts of forest Muridae under the large-scale mapping of their distribution. Zool. Ž. 7: 1079-1085. [In Russian with English summary]

Mazurkiewicz M. 1984. Population density of small rodents as affected by chosen elements of tree stand structure. Bull. Acad. Pol. Sci., Cl II 32: 209-217. 
Mazurkiewicz M. 1986. The influence of undergrowth distribution on utilization of space by bank vole populations. Acta theriol. 31: 55-69.

Mazurkiewicz M. 1991. Population dynamics and demography of the bank vole in different tree stands. Acta theriol. 36: 207-227.

Mazurkiewicz M. 1994. Factors influencing the distribution of the bank voles in the forest habitats. Acta theriol. 39: 113-126.

Mazurkiewicz M. and Rajska-Jurgiel E. 1978. Size and structure of rodent community of various forest stand types. Bull. Acad. Pol. Sci., Cl II 10: 669-677.

Morris D. W. 1987. Ecological scale and habitat use. Ecology 68: 362-369.

Pelikán J. 1986. Small mammals in windbreaks and adjacent fields. Acta Sci. nat. Brno 20: 1-38.

Pucek M. 1983. Habitat preference. [In: Ecology of the bank vole. K. Petrusewicz, ed]. Acta theriol. 28, Suppl. 1: 31-40.

Rosenzweig M. L. and Winakur J. 1969. Population ecology of desert rodent communities: habitats and environmental complexity. Ecology 50: 558-572.

Southern M. N. and Lowe V. P. M. 1968. The pattern of distribution of prey and predation in towny owl territories. J. Anim. Ecol. 37: 75-97.

Watts C. H. S. 1968. The food eaten by wood mice (Apodemus sylvaticus) and bank voles (Clethrionomys glareolus) in Wytham Woods, Berkshire. J. Anim. Ecol. 37: 25-41.

Wiger R. 1982. Roles of self regulatory mechanisms in cyclic populations of Clethrionomys with special reference to C. glareolus, a hypothesis. Oikos 38: 60-71.

Zar J. H. 1984. Biostatistical analysis. Prentice-Hall, Englewood Cliffs, New Jersey: 1-718.

Received 25 November 1993, accepted 31 March 1994. 
Appendix. List of plant species and their mean cover or density $\left(^{*}\right)$ per trap site on plots A and B. T - whole plot, DF - deciduous forest, ECO - ecotone, MCF - mixed coniferous forest, TT - tall trees, ST - short trees, SL - shrubs, HL - herbs.

\begin{tabular}{|c|c|c|c|c|c|c|c|c|c|}
\hline \multirow{2}{*}{ Plant species } & \multirow{2}{*}{ Abbr. } & \multicolumn{4}{|c|}{ Plot A } & \multicolumn{4}{|c|}{ Plot B } \\
\hline & & $\mathrm{T}$ & DF & ECO & $\mathrm{MCF}$ & $\mathrm{T}$ & DF & ECO & $\mathrm{MCF}$ \\
\hline 1 & 2 & 3 & 4 & 5 & 6 & 7 & 8 & 9 & 10 \\
\hline \multicolumn{10}{|l|}{ TT } \\
\hline Acer platanoides $\mathrm{L}$. & Apla & & & & & 1.00 & 2.30 & 0.00 & 0.00 \\
\hline Betula verrucosa Ehrh. & Bver & $0.50^{*}$ & $0.30^{*}$ & $0.50^{*}$ & $0.70^{*}$ & 2.10 & 3.50 & 0.10 & 1.20 \\
\hline Carpinus betulus L. & Cbet & $0.60^{*}$ & $1.60^{*}$ & $0.50^{*}$ & $0.20^{*}$ & 4.30 & 9.00 & 1.80 & 0.00 \\
\hline Picea abies (Lam.) Lk. & Pabi & & & & & 8.90 & 10.00 & 8.90 & 7.70 \\
\hline Pinus sylvestris L. & Psyl & $1.00^{*}$ & $0.50 *$ & $0.70^{*}$ & $1.50 *$ & 13.60 & 7.80 & 26.50 & 14.80 \\
\hline Quercus robur $\mathrm{L}$. & Qrob & $1.30^{*}$ & $1.40^{*}$ & $1.20^{*}$ & $1.30 *$ & 1.60 & 3.20 & 1.00 & 0.10 \\
\hline \multicolumn{10}{|l|}{ ST } \\
\hline Acer platanoides L. & Apla & & & & & 4.20 & 7.10 & 3.90 & 1.00 \\
\hline Betula verruco & Bver & $0.70^{*}$ & $0.07^{*}$ & $0.60^{*}$ & $1.10^{*}$ & 1.90 & 0.30 & 4.30 & 2.80 \\
\hline Carpinus betulus L. & Cbet & $7.40 * 1$ & $10.40^{*}$ & $6.80^{*}$ & $6.60^{*}$ & 21.20 & 34.50 & 25.30 & 4.00 \\
\hline Fraxinus excelsior $\mathrm{L}$. & Fexc & & & & & 0.40 & 0.80 & 0.01 & 0.00 \\
\hline Picea abies (Lam.) Lk. & Pabi & & & & & 8.30 & 5.00 & 8.30 & 12.00 \\
\hline Pinus sylvest & Psyl & $0.10^{*}$ & $0.00^{*}$ & $0.02 *$ & $0.40^{*}$ & & & & \\
\hline Quercus robur L. & Qrob & $3.70^{*}$ & $1.80^{*}$ & $3.50^{*}$ & $4.90^{*}$ & 6.40 & 4.00 & 8.40 & 8.20 \\
\hline \multicolumn{10}{|l|}{ SL } \\
\hline Acer platanoides $\mathrm{L}$. & Apla & & & & & 1.00 & 0.30 & 0.60 & 1.90 \\
\hline Betula verrucosa Ehrh. & Bver & $0.30^{*}$ & $0.00^{*}$ & $0.40^{*}$ & $0.50 *$ & & & & \\
\hline Carpinus betulus L. & Cbet & $8.50^{*}$ & $8.80^{*}$ & $9.60^{*}$ & $7.20^{*}$ & 5.30 & 8.40 & 5.90 & 1.40 \\
\hline Corylus avellana $\mathrm{L}$. & Cave & $7.80^{*}$ & $6.00^{*}$ & $8.40 *$ & $7.90^{*}$ & 11.80 & 12.90 & 17.10 & 8.20 \\
\hline Frangula alnus Mill. & Faln & $73.60^{*} 1$ & $18.40^{*} \epsilon$ & $62.00 * 1$ & $112.10^{*}$ & & & & \\
\hline Juniperus cc & Jcom & $0.90^{*}$ & $0.02 *$ & $0.70^{*}$ & $1.60^{*}$ & & & & \\
\hline Malus sylvestris & Msyl & $0.01^{*}$ & $0.00^{*}$ & $0.01^{*}$ & $0.02 *$ & & & & \\
\hline Picea abies (Lam.) Lk. & Pabi & & & & & 12.60 & 2.80 & 13.00 & 23.90 \\
\hline Populus tremula L. & Ptre & $0.10^{*}$ & $0.02 *$ & $0.20^{*}$ & $0.07 *$ & & & & \\
\hline Quercus robur L. & Qrob & $1.60^{*}$ & $0.30 *$ & $1.00^{*}$ & $2.80^{*}$ & 4.50 & 0.01 & 1.10 & 11.30 \\
\hline Rubus idaeus L. & Rida & $2.60^{*}$ & $0.10^{*}$ & $4.40^{*}$ & $1.60^{*}$ & 0.80 & 0.10 & 1.10 & 1.60 \\
\hline Sorbus aucuparia L. & Sauc & $2.00 *$ & $2.10^{*}$ & $2.40^{*}$ & $1.60^{*}$ & 1.30 & 0.10 & 1.00 & 2.70 \\
\hline Tilia cordata Mill. & Tcor & $0.40^{*}$ & $0.05^{*}$ & $0.50^{*}$ & $0.30^{*}$ & & & & \\
\hline Viburnum lantana L. & Vlan & $0.04^{*}$ & $0.02^{*}$ & $0.05^{*}$ & $0.03^{*}$ & & & & \\
\hline \multicolumn{10}{|l|}{ HL } \\
\hline Aegopodium podagraria L. & Apod & & & & & 1.30 & 2.90 & 0.00 & 0.00 \\
\hline Ajuga reptans $\mathrm{L}$. & Arep & & & & & 0.40 & 0.80 & 0.10 & 0.00 \\
\hline Anemone nemorosa L. & Anem & 2.60 & 2.50 & 3.30 & 1.90 & & & & \\
\hline Asarum europaeum L. & Aeur & & & & & 3.30 & 7.40 & 0.10 & 0.01 \\
\hline Asperula odorata L. & Aodo & & & & & 1.10 & 2.40 & 0.00 & 0.05 \\
\hline Bryophyta & Bry & 1.00 & 0.20 & 0.50 & 1.90 & & & & \\
\hline Calamagrostis arundinacea (L.) Roth & Caru & 2.60 & 0.30 & 1.70 & 4.70 & 2.60 & 0.00 & 0.30 & 6.60 \\
\hline Carex L. & Car & 3.10 & 2.70 & 3.40 & 2.80 & 0.80 & 0.40 & 2.90 & 0.40 \\
\hline Convallaria maialis $\mathrm{L}$. & Cmai & 6.00 & 6.80 & 7.10 & 4.30 & 0.40 & 0.10 & 0.30 & 0.70 \\
\hline Daphne mezereum L. & Dmez & & & & & 0.10 & 0.20 & 0.01 & 0.00 \\
\hline
\end{tabular}


Appendix - concluded

\begin{tabular}{|c|c|c|c|c|c|c|c|c|c|}
\hline 1 & 2 & 3 & 4 & 5 & 6 & 7 & 8 & 9 & 10 \\
\hline Evonymus verrucosa Scop. & Ever & & & & & 0.20 & 0.40 & 0.20 & 0.10 \\
\hline Fragaria vesca $\mathrm{L}$. & Fves & & & & & 0.70 & 0.30 & 0.30 & 1.30 \\
\hline Galeobdolon luteum Huds. & Glut & 0.10 & 0.20 & 0.04 & 0.01 & 7.30 & 14.50 & 4.90 & 0.00 \\
\hline Galeopsis speciosa Mill. & Gspe & & & & & 0.50 & 1.00 & 0.20 & 0.02 \\
\hline Geum urbanum $\mathrm{L}$. & Gurb & & & & & 0.10 & 0.30 & 0.01 & 0.01 \\
\hline Hepatica nobilis Garsault & Hnob & & & & & 4.20 & 8.60 & 2.00 & 5.10 \\
\hline Lathyrus vernus (L.) Bernh. & Lver & & & & & 0.50 & 1.10 & 0.00 & 0.00 \\
\hline Luzula pilosa (L.) Willd. & Lpil & & & & & 0.20 & 0.03 & 0.10 & 0.30 \\
\hline Majanthemum bifolium (L.) F.W.Schm. & Mbif & & & & & 1.30 & 0.80 & 2.80 & 1.20 \\
\hline Melampyrum pratense $\mathrm{L}$. & Mpra & 0.60 & 0.10 & 0.40 & 1.00 & & & & \\
\hline Mercurialis perennis $\mathrm{L}$. & Mpar & & & & & 2.00 & 4.40 & 0.00 & 0.00 \\
\hline Milium effusum L. & Meff & 0.20 & 0.60 & 0.10 & 0.02 & 0.50 & 1.00 & 0.50 & 0.03 \\
\hline Mycelis muralis (L.) Dum. & Mmur & & & & & 0.10 & 0.10 & 0.10 & 0.10 \\
\hline Oxalis acetosella $\mathrm{L}$. & Oace & & & & & 17.70 & 24.50 & 27.10 & 5.90 \\
\hline Paris quadrifolia $\mathrm{L}$. & Pqua & & & & & 0.20 & 0.30 & 0.04 & 0.00 \\
\hline Polygonatum multiflorum (L.) All. & Pmul & 0.10 & 0.30 & 0.10 & 0.01 & 0.20 & 0.50 & 0.00 & 0.01 \\
\hline Pteridium aquilinum (L.) Kuhn & Paqu & 10.20 & 3.40 & 13.20 & 9.90 & 2.10 & 3.60 & 1.70 & 0.50 \\
\hline Pulmonaria obscura Dum. & Pobs & & & & & 3.00 & 6.70 & 0.02 & 0.00 \\
\hline Ribes nigrum $\mathrm{L}$. & Rnig & & & & & 0.20 & 0.30 & 0.10 & 0.03 \\
\hline Stellaria holostea L. & Shol & 0.30 & 0.70 & 0.50 & 0.10 & 2.10 & 4.30 & 0.90 & 0.10 \\
\hline Trientalis europaea $\mathrm{L}$. & Teur & 0.40 & 0.10 & 0.30 & 0.60 & 1.00 & 0.00 & 0.20 & 2.50 \\
\hline Urtica dioica $\mathrm{L}$. & Udio & & & & & 1.40 & 3.20 & 0.10 & 0.01 \\
\hline Vaccinium myrtillus L. & Vmyr & 5.70 & 0.60 & 4.80 & 9.00 & 10.00 & 0.20 & 8.30 & 22.10 \\
\hline Vaccinium vitis-idaea $\mathrm{L}$. & Vvit & 0.10 & 0.00 & 0.04 & 0.20 & 0.90 & 0.00 & 0.00 & 2.30 \\
\hline Viola sylvestris Rchb. & Vsyl & & & & & 0.20 & 0.40 & 0.10 & 0.10 \\
\hline
\end{tabular}

